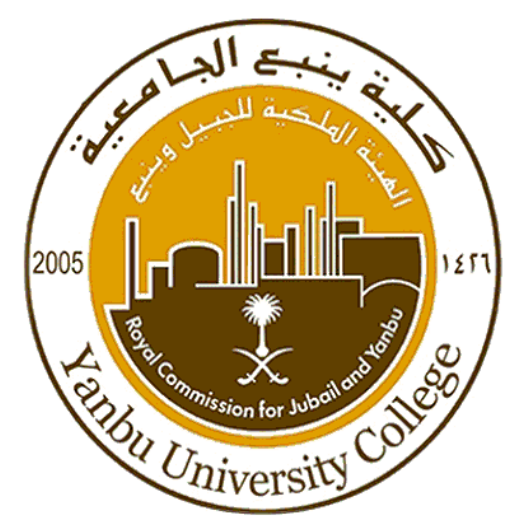

\title{
Aggression in Cyber Sphere: A Qualitative Study to Explore Saudi Arabian Social Media
}

\section{Dr. Ali Albar}

Computer Science and Engineering Department

Yanbu University College

Yanbu Industrial City, Royal Commission, Saudi Arabia e-Mail: albara@rcyci.edu.sa 


\section{Introduction}

Cyber aggression came about as a result of advances in information communication technology and the aggressive usage of the technology in real life. Nowadays, cyber aggression can take on many forms and faces.

The effect generated from cyber aggression is intended to be social, emotional, and psychological more than physical; however, a number of researchers admitted that these effects could lead to physical aggression (e.g. pushing), violence (e.g. fighting), and crimes (e.g. homicide or suicide). 


\section{Introduction}

Traditional aggression could be transferred to the digital world and present similar or worse psychological impacts.

(Cook, Williams, Guerra, \& Tuthill, 2007; Dooley, Pyzalski \& Cross, 2009; Ito et al., 2010; Zweig, Dank, Lachman, \& Yahner, 2013)

Cyber aggression is not well investigated across cultures. 


\section{Problem Statement}

The number of Internet users in Saudi Arabia increased from 1 million to 20 million in recent years.

Monitoring of Internet traffic and full control of all interactions is impossible.

Cyber aggression could be generated by the uncontrolled interactions. 


\section{Problem Statement}

The analysis of collected quantitative data from 500 participants indicated that more than $70 \%$ of the participants in Saudi Arabia answered that they have never seen or heard about cyberbullying.

With this high percentage, Saudi Arabia ranked with the lowest awareness about cyber aggression among the selected 24 countries in Ipsos study. 


\section{Purpose of the Research}

To explore the concept of cyber aggression in Saudi Arabia.

To find factors that could explain the level of cyber aggression in Saudi Arabia. 


\section{Research Question}

What factors could explain cyber aggression in Saudi Arabian social media? 


\section{Research Method}

The data collection methodology was intended to collect qualitative and descriptive data.

Conducted 14 in-depth interviews with Saudi male and female Students who use social media applications.

Recorded in-depth interviews transcribed into texts.

All created transcripts were analyzed by using content analysis (Colaizzi's Method). 


\section{Research Results}

\section{Significant Statements Releated to Cyberbullying}
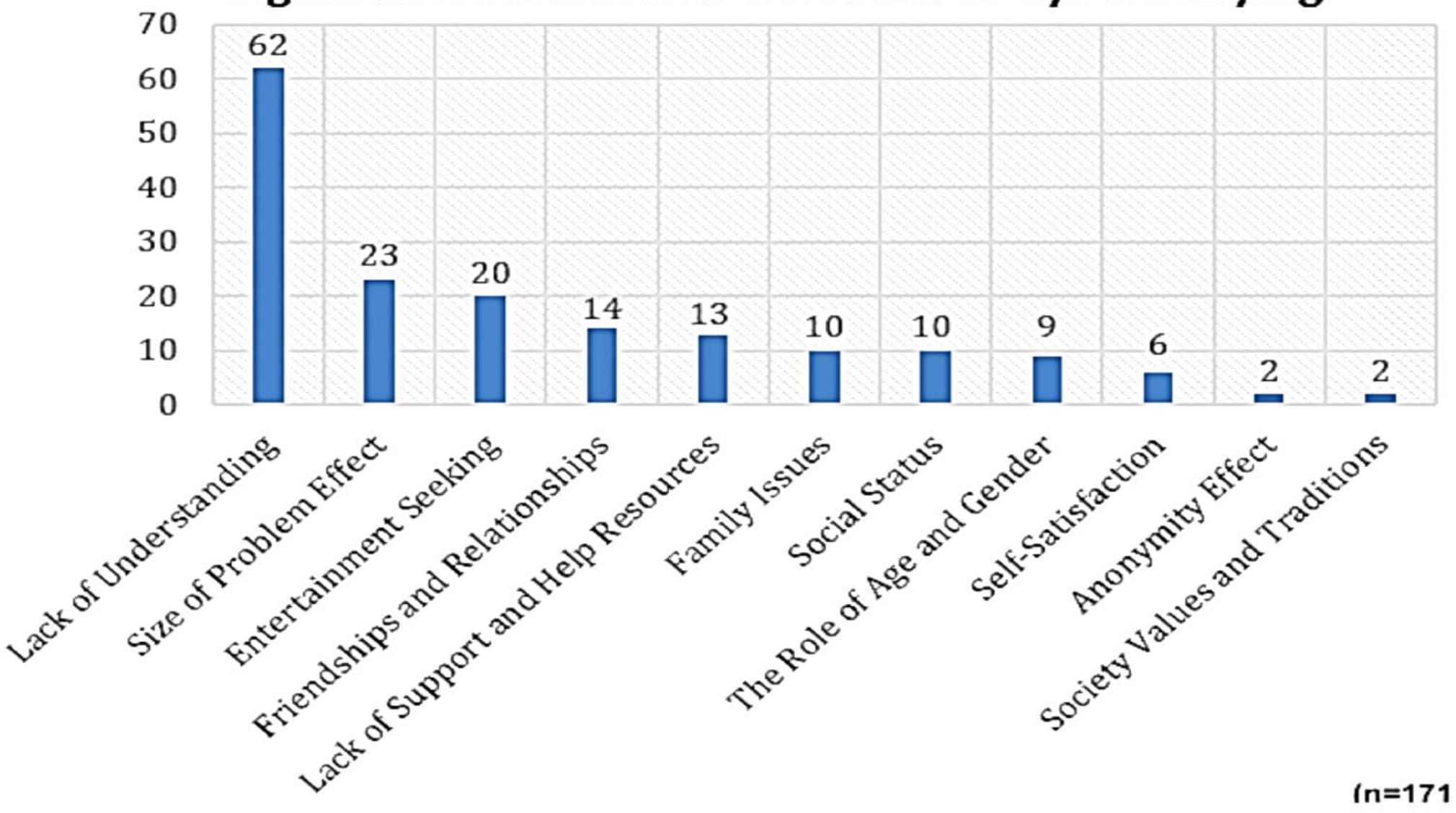


\section{Research Results}

\section{Significant Statements Related to Cyberstalking}

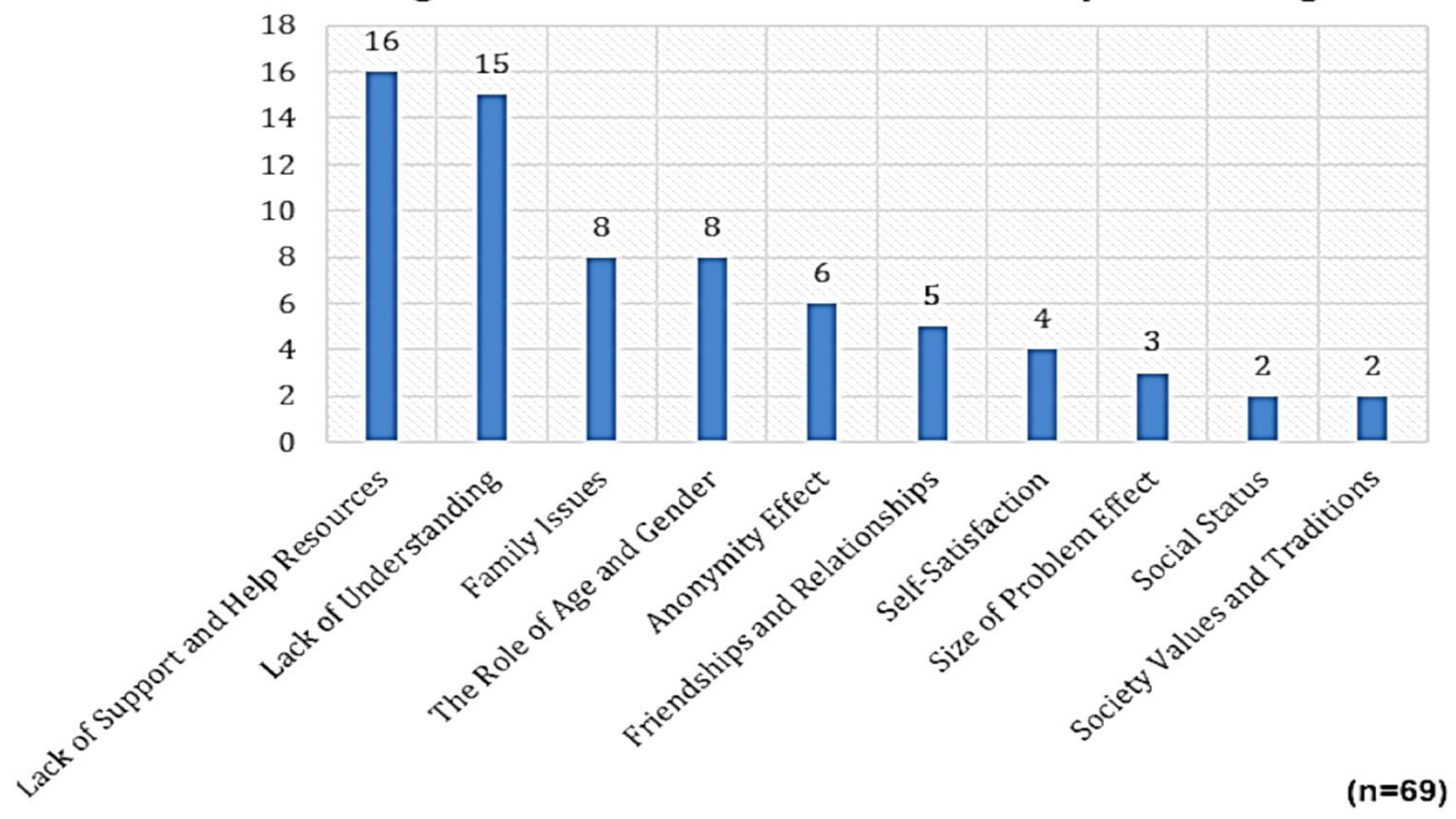




\section{A Proposed Cyber Aggression Model}

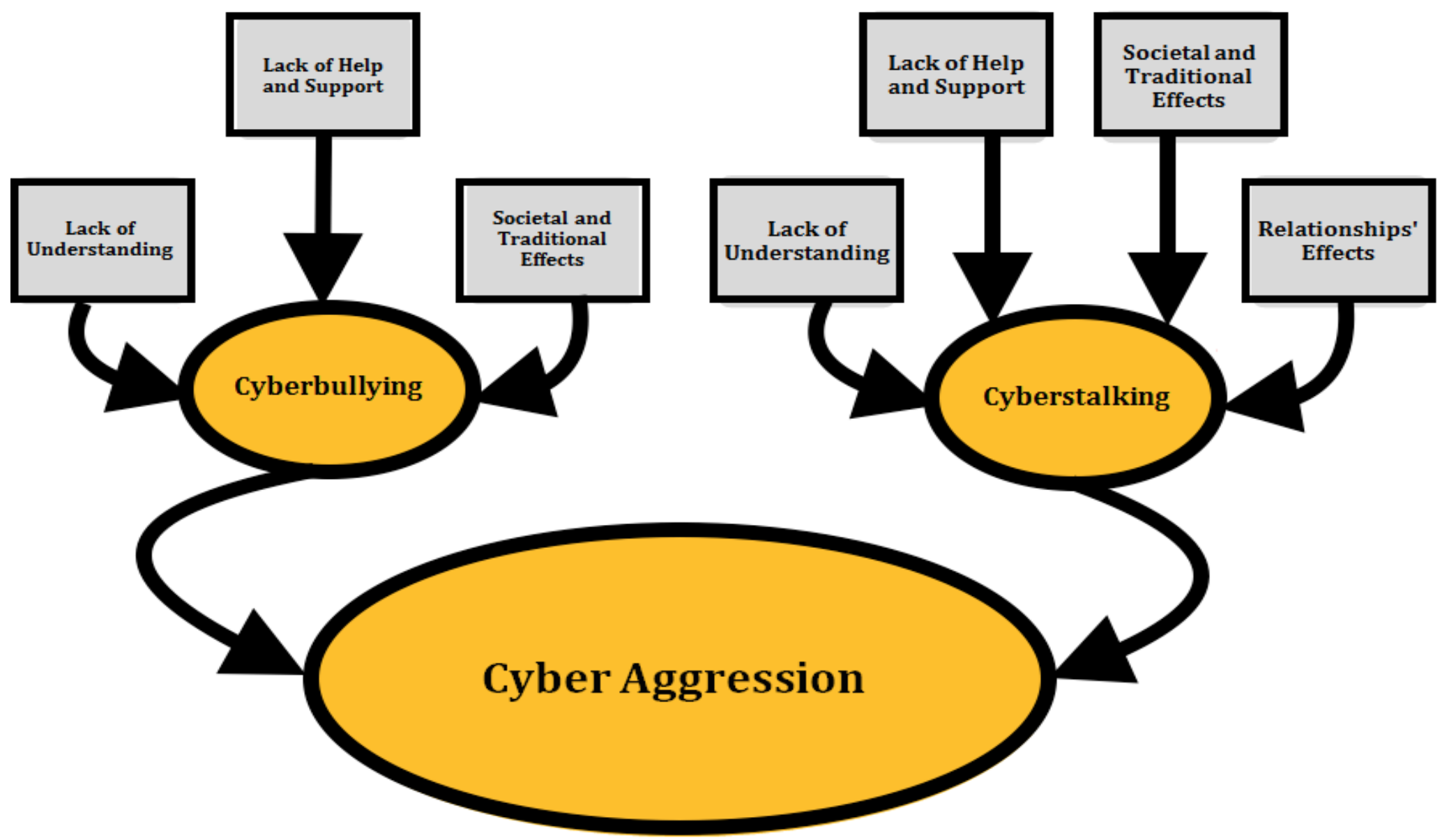




\section{Discussion \& Conclusions}

What factors could explain cyber aggression in Saudi Arabian social media?

Lack of understanding was found with the highest number of extracted significant statements (Cyberbullying:36\%, Cyberstalking: 22\%, total statements: 78 statements).

Social media users have a very limited understanding about cyber aggression, which make social media an unsafe domain for most social media users in Saudi Arabia. 


\section{Discussion \& Conclusions}

The research showed that participants choose to use social media without understanding cyberbullying and cyberstalking.

The majority of participants considered cyberbullying acts as childish, which could indicate that Saudi society does not give higher attention to many cyber aggressive acts.

Lack of support and help was another factor with a high number of extracted significant statements (8\%, 23\%, 29 statements). 


\section{Limitations of the Research}

A larger sample could provide more generalizable factors that could comprehensively explain cyber aggression.

Participants of this research represent the educated and tolerated society of Saudi Arabia. More diverse samples are required to assure the generalizability of the findings. 


\section{References}

Al-Jabre, A. (2013). Social networking, social movements, and Saudi Arabia: A review of literature. ARPN Journal of Science and Technology, 3(2), 161-168.

Al-Zahrani, A. M. (2015). Cyberbullying among Saudi's higher-education students: Implications for educators and policymakers. World Journal of Education, 5(3), 15-26.

CITC. (2014). Annual Report 2014. Communication and Information Technology Commission. 1-98. Retrieved from http://www.citc.gov.sa/English/MediaCenter/Annualreport/Documents/PR_REP_010Eng.pdf

Colaizzi, P. (1978). Psychological research as the phenomenologist views it. In R.S. Valle \& M. King (Eds.). Existential phenomenological alternatives for psychology (pp. 48-71). Oxford, UK: Oxford University Press.

Cook, C. R., Williams, K. R., Guerra, N. G., \& Tuthill, L. (2007). Cyberbullying: What it is and what we can do about it. NASP Communiqué, 36(1), 45.

Dooley, J. J., Pyżalski, J., \& Cross, D. (2009). Cyberbullying versus face-to-face bullying: A theoretical and conceptual review. Zeitschrift Für Psychologie/Journal of Psychology, 217(4), 182-188.

Hinduja, S., \& Patchin, J. W. (2010). Bullying, cyberbullying, and suicide. Archives of Suicide Research, 14(3), $206-221$.

Hinduja, S., \& Patchin, J. W. (2014). Bullying beyond the schoolyard: Preventing and responding to cyberbullying. Thousand Oaks, CA: Corwin Press.

Ipsos Global @dvisor. (2011). CYBERBULLYING: Citizens in 24 countries assess bullying via information technology for a total global perspective. ( No. G@27).Global Research Company Ipsos. Retrieved from http://www.ipsos-na.com/download/pr.aspx?id=14179

Ito, M., Antin, J., Finn, M., Law, A., Manion, A., Mitnick, S., .. . Horst, H. A. (2010). Hanging out, messing around, and geeking out: Kids living and learning with new media. Cambridge MA: MIT press.

The Social Clinic. (2015). The State of Social Media in Saudi Arabia, vol.3. Retrieved from http://www.thesocialclinic.com/the-state-of-socialmedia-in-saudi-arabia-vol-3/

Zweig, J. M., Dank, M., Lachman, P., \& Yahner, J. (2013). Technology, teen dating violence and abuse, and bullying. ( No. 2010-WG-BX-003). WASHINGTON, DC: URBAN INSTITUTE Justice Policy Center. Retrieved from http://www.iacpyouth.org/portals/0/resources/teen dating violence.pdf 


\section{Contact Info.}

Dr. Ali Albar

Assistant Professor

Computer Engineering - Program Coordinator

Computer Science and Engineering Department

Yanbu University College

P.O Box 31387 Yanbu Industrial City

Kingdom of Saudi Arabia

Cell_Phone: +966505522558

Office_Phone: +966143946100 Ext. 1580

Cisco_Phone: 1580

Office_No.: YUC-J1-91

eMail: albara@rcyci.edu.sa

Website: $\quad$ www.ali-albar.com 